\title{
IMPLEMENTASI PENDIDIKAN KARAKTER DI MADRASAH IBTIDAIYAH NEGERI (MIN) 1 KOTA MATARAM TAHUN 2018
}

\author{
Muhammad Musfiatul Wardi \\ Program Studi PGMI, Universitas Muhammadiyah Mataram, Indonesia \\ musfet14@gmail.com
}

\section{INFO ARTIKEL}

Riwayat Artikel:

Diterima: 05-08-2019

Disetujui: 30-10-2019

\section{Kata Kunci: \\ Implementasi; \\ Pendidikan karakter; \\ Madrasah Ibtidaiyah.}

\section{Keywords:}

Implementation

Character education;

Madrasah Ibtidaiyah.

\section{A. LATAR BELAKANG}

Menurut UU nomor 20 tahun 2003 tentang sistem pendidikan nasional, Pendidikan adalah usaha sadar dan terencana untuk mewujudkan suasana belajar dan proses pembelajaran agar peserta didik secara aktif mengembangkan potensi dirinya untuk memiliki kekuatan spiritual keagamaan, pengendalian diri, kepribadian, kecerdasan, akhlak mulia serta keterampilan yang diperlukan dirinya, masyarakat bangsa dan negara. ${ }^{1}$ Undang-undang diatas menjelasakan arti pentingnya pendidikan untuk membentuk kepribadian secara utuh, memacu diri mengembangkan setiap potensi yang dimiliki dan sebagai tolak ukur dari identitas diri, sehingga para peserta didik mampu berperan secara aktif dalam kegiatan pembelajaran.

Sesuai dengan fungsi dan tujuan pendidikan nasional sebagaimana tercantum dalam Undang-Undang sistem pendidikan nasional, yaitu UU No. 20.Tahun 2003 berbunyi: pendidik nasional bertujuan untuk berkembangnya potensi peserta didik agar menjadi manusia yang beriman dan bertakwa kepada Tuhan Yang Maha Esa, berakhlak mulia, sehat, berilmu, cakap, kreatif, mandiri dan menjadi warga negara yang demokratis, serta bertanggung jawab. ${ }^{2}$ Pasal tersebut merupakan dasar bagi pengembangan pendidikan karakter untuk membentukan karakter manusia khususnya generasi muda yang perlu ditanamkan sejak usia sekolah dasar pada anak. 
Hal ini dapat kita lihat dari bagaimana keseriusan pemerintah untuk mengoptimalkan fungsi dan mewujudkan tujuan pendidikan nasional diatas, yang tampak dari adanya kebijkan pendidikan karakter yang disuarkan sejak tahun 2003. ${ }^{3}$ Kebijakan pemerintah tersebut menjadi suatu usaha untuk menanamkan pendidikan karakter pada diri anak.

Munculnya kebijakan pemerintah tersebut tentu saja dilatar belakangi oleh kompleksitas permasalahan seputar karakter atau moralitas anak bangsa yang telah menjadi pemikiran sekaligus keprihatinan bersama semua komponen bangsa. ${ }^{4}$ Krisis karakter tersebut merupakan alasan utama dari berbagai penyimpangan yang terjadi.

Krisis karakter atau moralitas ini ditandai oleh meningkatnya kejahatan tindak kekerasan, penyalahgunaan obat terlarang (narkoba), pornografi dan pornoaksi, serta pergaulan bebas atau seks bebas yang sudah menjadi masalah sosial dalam masyarakat. Permasalahan mengenai karakter ini seakan semakin komplit tatkala para pelajar sering melakukan tawuran, bolos sekolah, melakukakan kekerasan pada temannya dan hal lain yang merugikan dirinya ataupun orang lain. ${ }^{5}$

Contohnya saja di berbagai wilayah di Indonesia, terjadi hal-hal tersebut, seperti, di Jawa Timur sejumlah siswa sekolah dasar kelas 5 telah mengisap rokok elektrik atau vape yang terekam di salah satu video.6 Sangat disayangkan anak usia sekolah dasar yang dibawah umur seharusnya giat belajar, namun melakukan hal sebaliknya.

Adapun contoh kasus yang terjadi di Cinare Depok seorang bocah SD berumur 12 tahun melakukan penusukan pada teman sekolahnya karena kehilangan sebuah $\mathrm{HP},{ }^{7}$ dan berita yang baru-baru beredar yakni, di SDN 4, kecamatan Terara kabupaten Lombok Timur, seorang guru honorer tewas dipukul oleh orang tua/wali murid dari salah satu peserta didik, dikarenakan sebuah perkelahian yang dilakukan oleh peserta didik tersebut bersama temannya dan guru tersebut berusaha memisahkannya. ${ }^{8}$ Perkelahian saja sudah

${ }^{3}$ Agus Wibowo, Pendidikan Karakter: Strategi Membangun Karakter Bangsa Berkepribadian, (Yogyakarta: Pustaka Pelajar, 2012), 30 .

${ }^{4}$ Nurul Zuriah, Pendidikan Moral \& Budi Pekerti dalam Persfektif Perubahan, (Jakarta: PT. Bumi Aksara, 2011), 10.

${ }^{5}$ Fatchul Mu'in, Pendidikan Karakter Konstruksi Teorotik \& Praktik, (Jogjakarta: Ar-Ruzz Media,2016),.26.

${ }^{6}$ Koran

Kompas,http://regional.compas.com/read/2017/10/24/Langkah Bupati Tringgalek Atasi Video Siswa Isap Rokok Elektrik, diunduh tanggal 27 Januari 2018

${ }^{7}$ Koran Kompas,http:www.kompasiana.com/iraannisa/anak SD Melakukan Pembunuhan Berencana Terhadap Temannya, diunduh tanggal 13 Januari 2018

${ }^{8}$ Koran Radar Lombok, Orang Tua Murid Pukul Guru Honorer di Lombok Timur, Rabu 7 Februari 2018 mampu menjadi masalah yang sangat besar baik bagi guru ataupun wali murid, dimana guru yang seharusnya dihormati dan dijunjung tinggi atas segala ilmu pengetahuan yang diberikan malah diperlakukan tidak adil.

Hal ini merupakan contoh kecil dari kasus krisis moral dan karakter yang di alami oleh Negara Indonesia, yang menjadi perhatian untuk kita semua khsusnya bagi para pendidik agar mampu membimbing dan mendidik peserta didik menjadi manusia yang beriman dan berahlak mulia, ${ }^{9}$

Fenomena sosial yang serba memprihatinkan diatas adalah sebuah renungan dan evaluasi bagi pendidikan kita selama ini, karena secara umum pendidikan harus mampu menghasilkan manusia sebagai individu dan sebagai anggota masyarakat yang sehat dan cerdas dengan keperibadian yang kuat dan religius serta mampu menjunjung tinggi budaya luhur bangsa. ${ }^{10}$ Oleh karenanya pendidikan adalah proses pembelajaran yang harus paling bertanggung jawab untuk menjadikan seseorang tidak hanya sekedar mengenal dan paham semata nilai-nilai kebaikan, melainkan sadar dan mengamalkan nilai-nilai kebaiakan tersebut dalam kehidupan sehari-hari sebagai karakter yang positif atau kepribadian yang mulia, dalam arti penanaman dan pengamalan nilai-nilai akan sangat berarti dalam kehidupan sehari-hari dibandingkan hanya sekedar hapal dan tahu. ${ }^{11}$

Dengan adanya pendidikan karakter inilah diharapkan mampu memberikan kontribusiya pada dunia pendidikan. Pendidikan karakter harus diterapkan oleh semua satuan pedidikan secara terintegrasi dalam pembelajaran dikelas, maupun diluar kelas, seperti kegiatan ekstrakuikuler, dan lain-lain.

Seperti yang ditanamkan oleh salah satu Madrasah yang berada di Kota Mataram sebagai salah satu Madrasah yang sudah mampu menerapkan pendidikan karakter yakni Madrasah Ibtidaiyah Negeri 1 Kota Mataram atau dapat disebut MIN 1 Kota Mataram.

\section{B. METODE PENELITIAN}

Penelitian ini termasuk dalam penelitian kualitatif, sebab itu pendekatan yang dilakukan adalah melalui pendekatan kualitatif deskriptif. Yaitu untuk memahami fenomena tentang apa yang dialami oleh subyek penelitian misalnya perilaku, persepsi, motivasi, tindakan, dan lain-lain,

9 Jamal Ma'mur Asmani, Buku Panduan Internalisasi Pendidikan Karakter Di Sekolah, (Jogjakarta: Diva Press,2011), 45.

${ }^{10}$ Sukarjo dan Ukim komarudin, Landasan pendidikan konsep dan aplikasinya, ( Jakarta: Rajawali Pers, 2013),60.

${ }^{11}$ Masnur Muslich, Pendidikan Karakter: Menjawab Tantangan Krisis Dimensional, (Jakarta: Bumi Aksara, 2014), 211. 
dengan cara deskripsi berupa ucapan, tulisan, dan prilaku orang-orang yang di amati.dalam bentuk kata-kata dan bahasa.. ${ }^{12}$ Sedangkan Suharismi Arikunto menegaskan bahwa peneitian deskriptif tidak dimaksudkan untuk menguji hipotesis tertentu, tetapi hanya menggambarkan " apa adanya " suatu variabel, gejala aatu keadaan.13 Maksudnya dalam penelitian kualitatif data yang dikumpulkan bukan berupa angka-angka melainkan data tersebut berasal dari naskah wawancara, catatan lapangan, dokumentasai pribadi, catatan memo dan dokumen resmi lainnya. ${ }^{14}$

Sehubungan dengan masalah penelitian ini, maka peneliti memiliki rencana kerja atau pedoman pelaksanaan penelitian dengan menggunakan pendekatan kualitatif dimana yang dikumpulkan berupa pendapat, tanggapan, informasi, konsep-konsep dan keterangan yang berbentuk uraian dalam mengungkapkan masalah.

Penelitian di samping perlu menggunakan metode yang tepat, juga perlu memilih teknik dan alat pengumpul data yang relevan, penggunaan teknik dan alat pengumpul data yang tepat memungkinkan diperolehnya data yang objektif. ${ }^{15}$ Dibawah ini akan diuraikan teknik atau metode penelitian sebagai cara yang dapat ditempuh untuk mengumpulkan data sebagai berikut:

1. Observasi

Observasi ini merupakan cara pengumpulan data dengan cara mengadakan pengamatan langsung dengan mendatangi obyek penelitian. ${ }^{16}$ Dalam penelitian ini peneliti mengunakan observasi non partisifatif (Non Participatory Observation), yaitu pengamat tidak ikut serta dalam kegiatan. ${ }^{17}$ yaitu peneliti hanya sebagai pengamat atau observator, peneliti tidak ikut mengambil bagian dari segala aspek yang diobservasikan. Adapun data yang akan peneliti kumpulkan melalui observasi yakni, proses pengimplementasian pendidikan karakter di MIN 1 Kota Mataram, yang meliputi berbagai kegiatan seperti:

a. Penanaman nilai-nilai karakter dalam kegiatan keagamaan dan ekstrakulikuler`

\footnotetext{
12 Andi Prastowo, Metode Penelitian Kualitatif dalam Perspektif Rancangan Penelitian, (Jogjakarta: Ar-ruzz Media, 2016),182.

${ }^{13}$ Suharismi Arikunto, Prosedur Penelitian Suatu Pendekatan Praktik, (Jakarta: PT. Rineka Cipta, 2010), 162.

${ }^{14}$ Basrowi dan Suwandi, Memahami Penelitian Kualitatif, (Jakarta: Rineka Cipta, 2008), 30.

${ }^{15}$ Margono, Metodologi Penelitian Pendidikan, (Jakarta: PT. Rineka Cipta, 2010), 158.

${ }^{16}$ Basrowi \& Suwandi, Memahami Penelitian Kualitatif, (Jakarta PT. Rineka Cipta, 2008), 99.

${ }^{17}$ Andi Prastowo, Metode Penelitian Kualitatif, (Yogyakarta: ArRuzz, 2011), 222-223.
}

b. Prilaku siswa saat proses belajar mengajar,misalnya jujur, disiplin, kerja keras, kreatif, dan lain-lain.

c. Pembiasaan pendidikan karakter melalui kreativitas siswa, misalnya pada saat kreativitas siswa berpidato siswa dapat berkreasi sekreatif mungkin dengan rasa ingin tahu yang luar biasa.

d. Bentuk-bentuk kegiatan rutin yang dilakukan di Madrasah

2. Interview atau Wawancara

Wawancara adalah percakapan dengan maksud tertentu oleh dua pihak yaitu pewawancara (Interviewer) sebagai pengaju atau pemberi pertanyaan, dan yang diwawancarai (Interviewee) sebagai pemberi jawaban. ${ }^{18}$. Adapun teknik wawancara yang digunakan adalah wawancara pembicaraan informal dimana jenis wawancara ini pertanyaan yang diajukan sangat bergantung pada pewawancara itu sendiri, jadi bergantung pada spontantitasnya dalam mengajukan pertanyaan kepada yang diwawancarai. ${ }^{19}$

Dalam hal ini peneliti akan melakukan wawancara dengan:

a. Kepala Madrasah terkait dengan proses pengimplementasian pendidikan karakter di MIN 1 Kota Mataram, hambatan-hambatan yang dihadapi saat penerapan pendidikan berlangsung.

b. Para guru, terkait dengan proses pembelajaran berlangsung, misalnya siswa sudah mengamalkan nilai-nilai pendidikan karakter yang diterapkan dan nilai-nilai tersebut sudah dicantumkan pada Rpp dan Silabus

c. Para peserta didik/siswa, terkait dengan nilainilai pendidikan karakter yang sudah diajarkan atau diterapkan dimadrasah, dan bentuknya seperti apa, misalnya melalui kegiatan keagamaan atau pembiasaan yang dicontohkan guru, seperti shalat berjamaah,dan lain-lain.

3. Dokumentasi

Dokumentasi adalah setiap bahan tertulis baik berupa karangan, memo, pengumuman, majalah, buletin, pernyataan, dan berita yang disiarkan kepada media masa. Dari uraian diatas, dokumentasi adalah pengumpulan data dengan meneliti catatan-catatan penting yang sangat erat hubunganya dengan obyek penelitian. ${ }^{20}$ Obyek yang diperhatikan dalam memperoleh informasi ada tiga macam sumber, yaitu tulisan (paper),

\footnotetext{
${ }^{18}$ Basrowi \& Suwandi, Memahami Penelitian Kualitatif, (Jakarta PT. Rineka Cipta, 2008), 127.

${ }^{19}$ Sugiyono, Metode Penelitian Pendidikan Pendekatan Kuantitatif, Kualitatif, dan R\&D, (Bandung: Alfabeta,2008), 220. ${ }^{20}$ Hamid Patilima, Metode Penelitian Kualitatif, (Bandung: Alfabeta, 2007), 85
} 
tempat (place),dan orang (people). ${ }^{21}$ Tujuan digunakan metode ini untuk mempermudah mendapatkan data seperti, data guru, siswa, kegiatan sekolah, proses belajar mengajar dikelas, sarana prasarana Madrasah, dan apa saja kegiatan yang bisa di dokumentasikan terkait implementasi pendidikan karakter di MIN 1 Kota Mataram.

Adapun data-data yang ingin peneliti ambil dari dokumentasi seperti gambaran umum MIN 1 Kota Mataram (Latar belakang, visi-misi, semboyan, Kegiatan Ekstrakulikuler dan Kegiatan keagamaan (pembiasaan), kegiatan rutin dan kreativitas siswa di MIN 1 Kota Mataram, serta kegiatan dalam proses belajar mengajar terkait penanaman nilai pendidikan karakter di dalam kelas.

\section{HASIL DAN PEMBAHASAN}

Madrasah Ibtidaiyah Negeri (MIN) 1 Kota Mataram adalah lembaga pendidikan Agama Islam setingkat SD yang berada dibawah naungan Kementerian Agama. Pada tanggal 1 Agustus 1981 MIN 1 Kota Mataram adalah merupakan lembaga pendidikan yang dibangun dengan swadaya masyarakat Punia Karang Kateng Kelurahan Mataram Barat Kecamatan Mataram yang diberi nama Madrasah Diniyah "Darul Arqom". Madrasah ini dibuat adalah hasil kesepakatan dari masyarakat Punia dan pengurus Madrasah didukung oleh para pemuka masyarakat (penghulu kelurahan) dengan bantuan penuh dari kepala kelurahan Mataram Barat. Dengan perintisan $\mathrm{H}$. Muhammad Munir, H. Rusdin, H. Ahmad Muhlis, Drs. H. Zohdi, H. Nurudin yang kesemuanya ini adalah merupakan pemuka-pemuka masyarakat dilingkungan Punia Karang Kateng diperkuat dengan dukungan kepala lingkungan setempat $(\mathrm{H}$. Nurtani).

MIN 1 Kota Mataram menyelenggarakan sistem dan pola pembelajaran yang mengacu pada undang-undang sistem pendidikan nasional, baik dalam mekanisme proses belajar mengajar, maupun dalam penggunaan metode pembelajaran, dan lain sebagainya, termasuk dalam implementasi pendidikan pembentukan karakter siswa.

Seperti yang dijelaskan bapak H. Marzuki, implementasi pendidikan karakter di MIN 1 Kota Mataram, di laksanakan melalui berbagai cara seperti penerapan saat proses belajar mengajar, yang di tuangkan dalam RPP dan silabus, khusnya pada K 13 yang setiap mata pelajaran dalam bentuk tema, di selipkan masing-masing karakter sesuai dengan tema yang di ajarkan. ${ }^{22}$

\footnotetext{
${ }^{21}$ Parsudi Suparlan, Metode Penelitian Kualitatif, (Jakarta:
} Program Kajian Wilayah Amerika-Universitas Indonesia, 1994), 66-67 Mataram
Selanjutya dalam kegiatan rutin setaip hari seperti kegiatan do'a bersama sebelum memulai pelajaran, para siswa berkumpul di lapangan, penanaman budaya 5 S (Senyum, Sapa, Salam, Sopan, Santun), dan kegiatan imtak pada hari jum'at dan upacaraa bendera setiap hari senin, hal tersebut merupakan salah satu upaya penanaman karakarter pada siswa dari kegiatan rutin yang secara terus menerus dilakukan. Namun implemntasi pendidikan karakter tidak hanya diterapkan dalam kegiatan rutin, seperti yang dijelaskan bapak H. Irwan, penerapan pendidikan karakter juga dilakukan dalam kegiatan ekstrakulikuler, masing-masing kegiatan ekstrakulikuler memilki nilai karakter masingmasing, misalnya pramuka, dapat di terapkan nilai mandiri, kerja keras, disiplin dan sebagainya. ${ }^{23}$

Segala bentuk implementasi pendidikan karakter yang di terapkan di MIN 1 Kota Mataram, mengacu pada beberapa model penerapan pendidikan karakter antara lain, keteladanan, dan pembiasaan, yang di lakukan sebagai suatu strategi dalam pencapaian pendidikan karakter dimana kedua bentuk model tersebut menjadi senjata utama yang dilakukan pihak Madrasah dalam menerapkan pendidikan karakter

Adapun implentasi pendidikan karakter di MIN 1 Kota Mataram untuk lebih jelasnya dapat di rincikan sebagai berikut :

\section{Nilai Religius}

Nilai religius dilaksanakan dalam kegiatan do'a bersama sebelum memulai pelajaran, semua siswa berkumpul dilapangan sesuai dengan kelas masing-masing, dan membaca surat-surat pendek, kemudian bershalawat yang dipimpin oleh salah satu siswa di pandu oleh salah seorang guru. ${ }^{24}$ Melaksanakan imtak setiap hari jum'at oleh warga MIN 1 Kota Mataram yang dirangkai dengan susunan acara dimulai dengan kegiatan shalat duha berjamaah yang diimami oleh siswa sendiri, membaca surat yasin, dan surat pendek, ceramah dan lain sebagainya. Kemudian kegiatan shalat dzuhur berjamaah, semua siswa di arahkan ke masjid pada saat bel waktu shalat berjamaah tiba, dan para guru yang bertugas mendampingi siswa dan mengawasinya, dan sebelum pulang sekolah. Semua siswa duduk di bangku masing-masing dengan kedua tangan melipat diatas meja, setelah semua rapi dan siap kemudian semua siswa berdo'a dipimpin oleh ketua kelas.

Dan dilakukan melalui kegiatan pembiasaan atau kegiatan rutin, untuk menumbuhkan rasa hormat dan sopan santun kepada bapak ibu guru,

\footnotetext{
${ }^{23}$ Wawancara, H. Irwan (Wakil kepala Madrasah),MIN 1 Kota Mataram.

${ }^{24}$ Observasi, Nilai Religius MIN 1 Kota Mataram
} 
serta menjalin hubungan yang baik dengn bapak ibu guru, kegiatan rutin yang dilakukan seperti yang dijelaskan waka kesiswaan ibu Hj. Saenah yakni pembiasaan 5S (Senyum, sapa, salam, sopan, santun) kegiatan ini merupakan langkah awal dari kegiatan yang dilakukan di madrasah. Pembiasaan 5S dimulai dari guru yang senantiasa menyambut murid-muridnya di pintu gerbang masuk sekolah. ${ }^{25}$

Senada dengan pendapat bapak H. Azazi selaku waka kurikulum menegaskan bahawa kegiatan ini bertujuan agar siswa terbiasa bersikap ramah dan berkelakuan baik, yakni menghormati orang yang lebih tua. ${ }^{26}$

2. Kejujuran

Nilai kejujuran diimplementasikan dengan memberi pengarahan tentang nilai kejujuran, misalnya ketika ada tugas mandiri yang dikerjakan, siswa mengerjaan sendiri, tidak mencontek dalam ulangan atau ada yang menemukan uang, barang dikelas atau halaman Madrasah, siswa mengembalikan pada teman yang merasa kehilangan atau memberikan barang tersebut pada bapak/ ibu guru, untuk diumumkan melaluai speaker atau pengeras suara agar siswa yang merasa kehilangan segera menemukan barangnya.

Pada saat observasi peneliti menemukan salah seorang siswa kelas 3A menemukan barang di dalam kelas ketika hendak memasuki ruang kelas, dikarenakan kelas 3A masuk setelah kelas 1A pulang, hal yang ditemukan berupa kotak makan yang tidak diketahui siapa pemiliknya,kemudian siswa tersebut memberikan barang tersebut kepada waka kesiswaan, ibu Hj. Saenah, agar di umumkan besok paginya. ${ }^{27}$

Kemudian peneliti memberikan beberapa pertanyaan sederhana kepada siswa tersebut terkait nilai kejujuran, kemudian siswa tersebut menjelaskan bahwa di MIN 1 Kota Mataram bapak ibu guru mengajarkan untuk tidak mengambil barang hak milik orang lain. ${ }^{28}$

Nilai kejujuran juga terlihat pada saat berbelanja di kantin Madrasah, siswa dan siswi membayar seharga makanan yang dibeli, siswa menaruh uang di atas dagangan yang ada di kantin, bila ibu kantin tidak bisa mengmbil langsung dari tangn anak karena banyak anak yang membeli makanan. ${ }^{29}$

\section{Toleransi}

Nilai toleransi atau saling menghargai dan menghormati diimplementasikan dengan cara memberikan pemahaman pada siswa, seperti yang dijelaskan bapak H. Irwan berbeda adalah bagian dari kehidupan, sehingga setiap perbedaan bukan untuk memisahkan tetapi menyatukan. Dimana anak-anak MIN 1 Kota Mataram terdiri dari banyak kalangan masyarakat yang memiliki kemampuan yang berbeda-beda dari segi ekonomi, ada yang kurang mampu, mampu, dan sebagainya, dengan inilah anak diajarkan untuk toleransi dan berbagi dengan cara membantu teman yang merasa kurang mampu, melalui kegiatan jum'at berbagi. ${ }^{30}$ Namun tidak hanya itu saja, penanaman nilai toleransi juga dilakukan pada saat proses belajar mengajar, seperti guru tidak membeda-bedakan siswanya, ketika pembagian kelompok, guru membaginya secara acak agar. Tidak hanya pintar dengan pintar dan sebaliknya, namun disesuaikan agar siswa dapat bergaul dengan temannya, disamping hal tersebut guru juga selalu mengingatkan kepada siswa, akan pentingnya saling menghargai segala perbedaan. ${ }^{31}$

Sehingga siswa dalam kesehariannya mampu bergaul dengan teman-temannya, tanpa membedabedakan teman, selain itu dalam kegiatan belajar mengajar, seperti yang di ungkap Bapak subki Ali guru Akidah Akhlak, bahwa di dalam kelas, pada saat proses belajar mengajar, guru menekankan bagaimana toleransi ketika siswa saling berpendapat, maupun berselisih paham, agar saling menghargai pendapat teman, dan apabila teman tidak dapat menjawab pertanyaan dari guru, teman yang lain tidak boleh mentertawakan, melainkann memberikan sebuah apresiasi (tepuk tangan) untuk menghargai upaya atau usaha yang dilakukan oleh temannya. ${ }^{32}$ Nilai toleransi tidak hanya diajarkan di Madrasah terkait toleransi sesama teman tetapi juga di ajarkan toleransi terhadap agama lain, misalnya ketika agama lain merayakan hari besar, mak harus tetap menghargai dan menghormatinya.

4. Disiplin

Nilai disiplin diupayakan oleh MIN 1 Kota Mataram, melalui disiplin waktu yang di contohkan oleh seluruh warga MIN 1 Kota Mataram, baik Kepala Madrasah, guru, dan siswa dengan datang ke madrasah tepat waktu dan menjalankan tata tertib madrasah. ${ }^{33}$ Jadi kedisiplinan yang terjadi di MIN 1 Kota Mataram tidak hanya pada siswa namun juga berlaku pada kepala madrasah, dan guru. Kepala madrasah mencontohkan siswanya dengan datang lebih pagi dari siswa agar siswa bisa meniru sikap kedisiplinan kepala madrasah.

\footnotetext{
${ }^{25}$ Wawancara, Hj. Saenah (waka kesiswaan).

${ }^{26}$ Wawancara, H. Azazi (waka kurikulum).

${ }^{27}$ Observasi, Nilai Kejujuran MIN 1 Kota Mataram

${ }^{28}$ Wawancara, Syakira Wirdiani (siswa kelas 3A).

${ }^{29}$ Observasi, Nilai Kejujuran MIN 1 Kota Mataram.
}

\footnotetext{
${ }^{30}$ Wawancara, H. Irwan (Wakil kepala madrasah)

${ }^{31}$ Observasi, Nilai Toleransi MIN 1 Kota Mataram.

${ }^{32}$ Wawancara, Subki Ali (guru mata pelajaran akidah akhlak).

${ }^{33}$ Observasi, Nilai Kedisiplinan MIN 1 Kota Mataram.
} 
Contoh lain seperti ketika bel berbunyi seluruh siswa sudah berada dilapangan dalam keadaan barisan yang rapi, untuk siap melakukan do'a bersama sebelum belajar, dan salah satu upaya lain yang diterapkan untuk melatih disiplin siswa yakni, pemberian kartu KMS (kartu menuju sholeh/sholeha) yang diberikan kepada siswa yang berisi kontrol jadwal kegiatan Madrasah, yang diisi oleh peserta didik, dan ditanda tangani oleh orang tua sebagai kontrol dirumah. ${ }^{34} \mathrm{Hal}$ ini juga merupakan upaya madrasah untuk bekerja sama dengan orang tua/wali murid untuk meningkatkan solidaritas madrasah.

Tidak hanya dalam hal itu saja,penanaman nilai disiplin juga diterapkan pada keseharian siswa di dalam kelas saat proses belajar mengajar, seperti yang dijelaskan ibu Nurtimah bahawa penanaman nilai kedisiplinan sangat penting dilakukan di dalam kelas saat proses belajar mengajar, anak harus diajarkan disiplin untuk masuk ke kelas, tidak boleh telat, berpakaian rapi, membawa perlengkapan sekolah, mengikuti pelajaran dengan tertib, dan sebagainyaKreatif

5. Nilai kreatif diimplementasikan melalui kegiatan rutin yang dibiasakan setiap hari jum'at yakni kegiatan kreativitas siswa, yang dilaksanakan setelah shalat duha berjamaah. Siswa yang bertugas diberikan kesempatan berkreasi tergantung kemampuan, ada yang ahli dalam berpidato, namun di kreasikan menjadi pidato dua bahasa indonesia dan bahasa arab, atau bahasa indonesia dan bahasa inggris, ada juga yang bermain drama, membawakan kisah-kisah tauladan, hapalan surat pendek, dan lain sebagainya. ${ }^{35}$ Nilai kreatif juga di implementasikan pada mata pelajaran seni budaya dimana anak dituntut untuk berkreasi sekreatif mungkin untuk meghasilkan suatu karya, yang akan dijadikan pajangan mading, dan juga diterapkan melalui ekstrakulikuler salah satu contohnya adalah ekstrakulikuler kaligrafi, yang menuntut kekreatifan siswa dalam menghasilkan suatu karya yang indah. ${ }^{36}$

6. Semangat Kebangsaan

MIN 1 Kota Mataram, menerapkan nilai semangat kebangsaan melalui kegiatan rutin yakni upacara bendera setiap hari senin, dan memperingati hari-hari besar, misalnya peringatan 17 agustus, madrasah sangat antusias terkait perayaan 17 agustus yakni persiapan lomba untuk para peserta didik dan juga guru, tidak hanya 17 agustus, peringatan hari pahlawan dan sumpah

\footnotetext{
${ }^{34}$ Observasi, Nilai Kedisiplinan MIN 1 Kota Mataram.

${ }^{35}$ Observasi, Nilai Kreatif MIN 1 Kota Mataram.

${ }^{36}$ Observasi, Nilai Mandiri MIN 1 Kota Mataram.
}

pemuda pun dilakukan untuk mengajarkan kepada siswa akan pentingnya semangat kebangsaan, serta berkunjung ke tempat-tempat bersejarah.

Namun upaya yang paling penting dilakukan MIN 1 Kota Mataram untuk menumbuhkan semangat kebangsaan yakni, memberikan pemahaman kepada siswa dengan cara menjelaskan perjuangan para pahlawan membela tanah air Indonesia dalam penjajahan yang dilakukan berbagai negara. ${ }^{37}$

7. Cinta Tanah Air

Cinta tanah air dimplementasikan di MIN 1 Kota Mataram dengan cara, menanamkan rasa nasionalisme dan rasa persatuan, dan kesatuan bangsa pada selurh warga Madrasah, terkait bagaimana mencintai tanah air Indonesia. Dan juga memajang gambar pancasila, gambar presiden, dan wakil presiden, dan simbol-simbol bangsa lainnya dan mengibarkan bendera merah putih. ${ }^{38}$

Cinta tanah air ditanamkan juga pada proses pembelajaran dimana anak-anak dicontohkan bagaimana mengunakan bahasa Indonesia yang baik dan benar, sebagai bentuk kecintaan terhadap bahasa persatuan yakni bahasa Indonesia.

\section{Peduli Lingkungan}

Nilai peduli lingkungan di implemen-tasikan melalui keteladanan, yang berkaitan langsung dengan guru, dimana guru sebagai suri tauladan bagi siswa, karna siswa akan cenderung meniru, apabila guru memiliki sikap baik, jujur ramah, dan sebagainya, maka secara tidak langsung siswa akan belajar dari keteladanan yang dimiliki seorang. Seperti yang dijelaskan Bapak Kepala Madrasah bahwa guru merupakan suri tauladan yang baik, yang akan menentukan baik dan buruknya siswa. ${ }^{39}$

Contohnya yang diterapkan di MIN 1 Kota Mataram, terkait Peduli lingkungan, seluruh guru memberikan contoh bagaimana menjaga lingkungan, misalnya membuang sampah pada tempatnya, jika menemukan sampah, guru tanpa terkecuali mengambil dan membuangnya, lebihlebih Kepala Madrasah yang sangat peduli terhadap lingkungan, sampah tidak akan dibiarkan ada dilingkungan sekolah, yang akan menganggu segala proses yang ada disekolah karna menyangkut kenyaman. Dan melakukan kegiatan gotong royong pada hari sabtu, yang merupakan kegiatan rutin, setelah kegiatan senam. ${ }^{40}$

9. Peduli Sosial

Peduli sosial, diimplementasikan melalui kegiatan pembiasaan jum'at berbagi dimana seluruh siswa memberikan sumbangan

\footnotetext{
${ }^{37}$ Observasi, Nilai Semangat Kebangsaan MIN 1.

${ }^{38}$ Dokumentasi, Nilai Semangat Kebangsaan MIN 1 Kota Mataram.

${ }^{39}$ Wawancara, H. Marzuki (kepala MIN 1 Kota Mataram).

${ }^{40}$ Obervasi. Nilai Peduli Lingkungan MIN 1 Kota Mataram.
} 
seikhlasnya, kegiatan ini dilakukan secara rutin setiap hari jum'at, dan uang yang disumbangkan akan disalurkan kepada pihak yang membutuhkan, misalnya menjenguk teman yang sedang sakit, bantuan untuk banjir Lombok Timur, dan bahkan ke Palestina.

10. Tanggung Jawab

Nilai tanggung jawab diimplementasikan di MIN 1 Kota Mataram, melalui pembiasan yang dilakukan guru, yakni mengerjakan pekerjaan rumah dengan tepat waktu, guru memberikan tugas wajib setiap minggunya, misalnya siswa harus merangkum mata pelajaran yang akan diajarkan mingggu depan, sebagai upaya agar siswa terbiasa bertanggung jawab mengerjakan pekerjaan rumah dengan sungguh-sungguh, mengerjakan tugas kelompok bersama-sama dan melakukan piket sesuai dengan jadwal piket yang telah ditentukan, yakni siswa yang mendapat piket diberikan tanggung jawab untuk datang lebih awal untuk membersihkan kelas, dan merapikan tepat duduk. Begitu juga yang mendapat tugas menjadi petugas imtak, upacara bendera harus datang lebih awal.

11. Komunikatif

Nilai komunikatif atau bersahabat diimplemantisakan, melalui keteladanan seorang guru, dimana para guru-guru MIN 1 Kota Mataram, memberikan kasih sayang yang tulus kepada para peserta didik, karena seorang guru adalah orang tua kedua di Madrasahah, tidak ada hanya itu guruguru MIN 1 Kota mataram tidak membedabedakan perlakuan terhadap siswa, meskipun siswa tersebut kaya,miskin, pintar, dan kurang pintar, jika melakukan kesalahan semuanya harus di hukum. ${ }^{41}$

Nilai komunikatif yang paling penting adalah guru-guru tidak menjaga jarak dengan para peserta didik, melainkan membangun sebuah komunikasi yang baik, dimana anak tidak sungkan untuk bertanya kepada guru, bahkan guru bisa seperti teman bermain untuk anak, lebih-lebih utuk anak didik kelas rendah yang masih sangat senang bermain, disini para guru terkadang bertingkah seperti anak kecil di dalam kelas untuk menyesuikan perkembangan peserta didik.

\section{SIMPULAN DAN SARAN}

Berdasarkan hasil penelitian dan pembahasan dapat ditarik kesimpulan bahwa implementasi pendidikan karakter di MIN 1 Kota Mataram sudah sangat baik meskipun terjadi beberapa kendala saat proses penerapannya. Hal ini dapat terlihat dari indikator kebehasilan pendidikan karakter, kemajuan dan berbagai prestasi yang di raih, terlihat dari berbagai kebijakan yang diterapkan Madrasah serta kesadaran selurh Madrasah untuk bekerja sama, sehingga MIN 1 Kota Mataram dapat dijadikan contoh oleh Madrasah lain dalam proses penerapan pendidikan karakter yang diterapkan melalui dua model pembelajaran berkarakter antara lain, pembiasaan, dan keteladanan, yang dilaksanakan melalui berbagai kegiatan yakni kegiatan ektrakulikuler, kegiatan rutin, kegiatan keagamaan, dan lain sebagainya.

Kendala-kendala yang dihadapi MIN 1 Kota Mataram terkait proses penerapan pendidikan karakter yang pertama antara lain berasal dari:

1. Siswa/ peserta didik yang di pengaruhi faktor lingkungan sekitar yang berdampak pada karakter masing-masing anak

2. Kedua, faktor dari guru terkait pemahaman dan kesulitan dalam mengaitkan tema dengan masig-masing nilai karakter, dikarenakan kurangnya pelatihan sehingga kurangnya profesionalisme menjadi seorang guru.

3. Sarana dan prasrana yang masih sangat kurang, untuk menunjang proses pelaksanaan pendidikan karakter di MIN 1 Kota Mataram. Seperti kurangnya ruang kelas, ruang perpustakaan, buku-buku pelajaran, dan media untuk menunjang keberhasilan proses pendidikan karakter tersebut.

Segala hal tersebut dapat tercapai tidak luput dari peran Kepala Madrasah, guru, dan wali murid yang terus bekerja sama untuk mensukseskan implementasi pendidikan karaker di MIN 1 Kota Mataram.

\section{DAFTAR RUJUKAN}

Undang-Undang Sistem Pendidikan Nasional No 20 Tahun 2013

Agus Wibowo, Pendidikan Karakter: Strategi Membangun Karakter Bangsa Berkepribadian, (Yogyakarta: Pustaka Pelajar, 2012)

Nurul Zuriah, Pendidikan Moral \& Budi Pekerti dalam Persfektif Perubahan, (Jakarta: PT. Bumi Aksara, 2011),

Fatchul Mu'in, Pendidikan Karakter Konstruksi Teorotik \& Praktik, (Jogjakarta: Ar-Ruzz Media,2016),

Jamal Ma'mur Asmani, Buku Panduan Internalisasi Pendidikan Karakter Di Sekolah, (Jogjakarta: Diva Press,2011)

Sukarjo dan Ukim komarudin, Landasan pendidikan konsep dan aplikasinya, ( Jakarta: Rajawali Pers, 2013), 
118 Ibtida'íy : Jurnal Prodi PGMI | Vol. 4, No. 2, Oktober 2019, hal. 111-118

Masnur Muslich, Pendidikan Karakter: Menjawab Tantangan Krisis Dimensional, (Jakarta: Bumi Aksara, 2014),

Nurul Zuriah, Pendidikan Moral dan Budi Pekerti dalam Perspektif Perubahan, (Jakarta: PT Bumi Aksara,2011)

Sukarjo dan Ukim komarudin, Landasan pendidikan konsep dan aplikasinya, (Jakarta: Rajawali Pers, 2013)

Dharma Kesuma, Pendidikan Karakter Kajian Teori Dan Praktik Di Sekolah, (Bandung: PT. Remaja Rosdakarya,2012)

Tuhana Taufik Adrianto, Mengembangkan Karakter Sukses Amak di Era Cyber, (Jogkakarta: ArRuzz Media,2011)

Thomas Lickona, Panduan Lengkap Mendidik Siswa Menjadi Pintar dan Baik, (Bandung: Nusa Media,201 4)

Masnur Muslich, Pendidikan Karakter: Menjawab Tantangan Krisis Dimensional, (Jakarta: Bumi Aksara, 2014),

Thomas Lickona, Panduan Lengkap Mendidik Siswa Menjadi Pintar dan Baik, (Bandung: Nusa Media,201 4),

Dharma Kesuma, Pendidikan Karakter Kajian Teori Dan Praktik Di Sekolah, (Bandung: PT. Remaja Rosdakarya,2012).

Tuhana Taufik Andrianto, Mengembangkan Karakter Sukses Anak di Era Cyber, (Jogkakarta: ArRuzz Media,2011),

Zubaedi, Desain Pendidikan Karakter Konsepsi dan Aplikasinya dalam Lembaga Penidikan, (Jakarta: Kencana Prenada Group,2011),

Syamsul Kurniawan, Pendidikan Karakter, Konsep dan Implemantasi Secara Terpadu di Lingkungan Keluarga, Sekolah, Perguruan Tinggi dan Masyarakat, ( Yogyakarta: Ar-Ruzz Media,2016). 